\title{
Immune-mediated gene expression of IL-6 and TGF- $\beta 1$ during progression and regression of canine transmissible venereal tumour
}

\author{
Kanika Tiwari ${ }^{1 *}$, Pushpa Verma ${ }^{1}$, Jaishree Sharma ${ }^{2}$, and Ajay K. Upadhyay ${ }^{2}$ \\ ${ }^{1}$ Department of Surgery and Radiology, College of Veterinary and Animal Science, G.B. Pant University of \\ Agriculture and Technology, Pantnagar, Dist.- Udham Singh Nagar, Uttarakhand, India \\ ${ }^{2}$ Department of Veterinary Public Health and Epidemiology, College of Veterinary and Animal Science, G.B. Pant \\ University of Agriculture and Technology, Pantnagar, Dist.- Udham Singh Nagar, Uttarakhand, India
}

TIWARI, K., P. VERMA, J. SHARMA, A. K. UPADHYAY,A. K. DAS: Immune-mediated gene expression of IL-6 and TGF- $\beta 1$ during progression and regression of canine transmissible venereal tumour. Vet. arhiv 91, 625-634, 2021.

\section{ABSTRACT}

Canine transmissible venereal tumor (CTVT) is a unique, naturally and experimentally transmitted contagious venereal tumor of dogs which is commonly present in stray dogs exhibiting unrestrained sexual activity. The mutated and contagious tumor cell is the causative agent. This study was conducted to evaluate the genetic expression of TGF- $\beta 1$ and IL- 6 cytokines, T-cell response towards Concanavalin A and hematological and biochemical changes during the progression and regression of the CTVT. The signalment and clinical history of 12 client-owned TVT affected dogs were recorded. Tissue samples were obtained through biopsy, and blood samples were collected for diagnostic confirmation using reverse transcriptase PCR. The RT-PCR products from CTVT samples were further purified and sequenced. Regression of the tumor was performed using intravenous injections of vincristine sulphate at weekly intervals. Significant genetic expression of TGF- $\beta 1$ was observed in the progressive phase of CTVT, whereas genetic expression of IL-6 was significant in the regressive phase of CTVT after chemotherapy. Cellmediated immunity also plays an important role in the regression of canine transmissible venereal tumors. Notably, a significant $(\mathrm{P}<0.05)$ increase in the mean stimulation index of the lymphocyte stimulation test and hemoglobin level, non-significant $(\mathrm{P}>0.05)$ changes in the number of neutrophils, lymphocytes, monocytes and eosinophils, and slight hypoproteinemia and hypoalbuminemia were observed after chemotherapy with vincristine sulphate in CTVT affected animals. Overall, our results delineate the critical roles of T cells, TGF- $\beta 1$ and IL-6 in triggering the progression and regression of CTVT, which can be promising in developing potential immunotherapy against CTVT.

Key words: canine transmissible venereal tumor; RT-PCR; TGF- $\beta 1$; IL-6; lymphocyte stimulation test; hematologic and biochemical changes; vincristine sulphate

\footnotetext{
*Corresponding author:

Kanika Tiwari, PhD scholar, Department of Surgery \& Radiology, College of Veterinary \& Animal Science, G.B. Pant University of Agriculture \& Technology, Pantnagar, India, E-mail: ttkanika13@gmail.com
} 


\section{Introduction}

Canine transmissible venereal tumor (CTVT) is a unique, contagious tumor widely spread in various regions of the world, mostly seen in tropical and subtropical countries. It is usually transmitted through viable cancer cells from affected dogs to susceptible hosts during coitus or other social behaviors (DAS and DAS, 2000). The tumor is mainly located in the external genital area but may also be found in other parts of the body, such as: the skin, eyes, nasal cavity and oral mucosa in the case of severely immunosuppressed dogs (DAS et al., 1989; MARCOS et al., 2006; MUKARATIRWA et al., 2006; LIN et al., 2010). The presence of stray dogs makes the disease difficult to control and necessitates sustained animal birth control in stray dogs, along with prompt treatment of affected dogs (GANGULY et al., 2016).

The three naturally occurring transmissible neoplastic diseases are known, canine transmissible venereal tumour (CTVT), Tasmanian devil facial tumour disease (DFTD) and the recently discovered leukaemia in molluscs, all exhibit different evolutionary phases. CTVT has coevolved with its canine hosts for over 10,000 years and appears to have reached an evolutionary equilibrium in its micro-environment (within the host) and macroenvironment (between hosts). In contrast, DFTD emerged about 20 years ago, and this tumor still shows signs of stepwise evolution characterized by rapid but minor phenotypic and genotypic alterations (UJVARI et al., 2016). Among these, CTVT is the oldest naturally occurring tumor which is remarkably stable and lacks subclonal heterogeneity (MURCHISON et al., 2014). Canine transmissible venereal tumor (CTVT) exhibits a three distinct growth phases in naturally and experimentally induced cases, i.e., progressive, stable and regression phases. The initial phase of the disease is the progressive phase which lasts for a few weeks, characterized by an active increase in the volume of the tumor with a typical doubling time of four to seven days and an estimated loss of $50 \%$ of cells due to apoptosis (CHU et al., 2001b). This is followed by the successive stable phase, characterized by the marked slower growth of the tumor, with doubling time of approximately 20 days and an estimated loss of $80-90 \%$ of cells occurring due to apoptosis. The final phase is the regressive phase which lasts from one week to several months, characterized by the shrinkage and disappearance of the tumor. Up to $80 \%$ of transmissible tumors enter a spontaneous regressive phase (CHU et al., 2001a). This spontaneous regression of the TVT may be regulated by different intrinsic or extrinsic factors, which include the products of neoplastic cells (necrotic or apoptotic cells, cytotoxic proteins) tumor infiltrating lymphocytes (TILs) and stromal cells (GONZALEZ et al., 2000; HSAIO et al., 2008; STOCKMANN et al., 2011).

During the progressive and regressive phases of CTVT, tumor cells secrete a high concentration of transforming growth factor beta-1 (TGF- $\beta 1$ ), which suppresses the major histocompatibility complex (MHC) class I and MHC class II expression. It also suppresses the immune activities of natural killer (NK) cells, dendritic cells, mature $\mathrm{T}$ cells, $\mathrm{B}$ cells, regulatory $\mathrm{T}$ cells and thymocytes (LIN et al., 2008). Due to its immunoregulatory effects, TGF- $\beta 1$ is involved in the growth and development of the tumor (STOVER et al., 2007; TEICHER, 2007). TGF- $\beta 1$ is a $25-\mathrm{kDa}$ homo-dimeric protein that has dynamic, pleiotropic and regulatory effects on mature $\mathrm{T}$ cells, B cells, regulatory $\mathrm{T}$ cells, thymocytes and natural killer (NK) cells (GORELIK and FLAVELL, 2001; WITHAM et al., 2003; CASTRICONI et al., 2003; LI et al., 2006). TGF- $\beta 1$ is also a multifunctional polypeptide which regulates various cellular processes, including growth, apoptosis, motility, differentiation and adhesion (RICH et al., 2001; CRANE and CAO, 2014; HAQUE and MORRIS 2017).

The transition of CTVT from the progressive to the regressive phase might be triggered by the induction of the major histocompatibility complex (MHC) expression, caused by cytokine signaling by tumor infiltrating lymphocytes (MURCHISON, 2008). CTVT cells produce TGF- $\beta 1$ which inhibits the natural killer (NK) cell activity and cytotoxicity of the tumor infiltrating lymphocytes. This suppressive effect of TGF- $\beta 1$ could be counter-balanced by the pro-inflammatory cytokine interleukin-6 (IL-6), secreted by tumor infiltrating lymphocytes (MURCHISON, 2008; HSIAO et al., 
2004). However, in the regressive phase, tumor infiltrating lymphocytes (TIL) secrete cytokine IL-6 that hinders the activities of TGF- $\beta 1$, and results in enhancement of the host immune system which rejects the viable transplanted cells (HSIAO et al., 2002; HSIAO et al., 2004). IL-6 is present in the TIL supernatants of both the progressive and regressive phases, and its concentration is significantly higher in the regressive phase of the TIL supernatant (HSIAO et al., 2004), which improves the immunity of the host. Hence, CTVT is one of the few tumors that allow us to study the detailed dynamic changes in host-tumor interactions during the spontaneous regression of transmissible venereal tumors.

As the immune system plays an important role in the development of canine transmissible venereal tumors (CTVT), occurrence of the disease represents the success of the neoplasm in dominating immune status of the host. In experimentally infected immune-compromised animals with viable venereal tumor cells, progression of the disease and metastasis were observed. Those dogs who recovered from this tumor, acquire immunity against successive implantations (MUKARATIRWA and GRUYS, 2003). Cellular immunity measured by a simplified whole blood lymphocyte stimulation test looks to be even more clinically useful in canine transmissible venereal tumors than other immunodiagnostic tests.

Concanavalin A is a lectin obtained from the jack bean (Canavalis ensiformis), characterized by D-mannose and D-glucose sugar moieties binding capabilities, and is useful for carbohydrate studies, glycoprotein purification, enzyme tagging, cell membrane studies, cell agglutination and cell typing. In cell culture applications, it has the ability to induce mitogenic activity of T-lymphocytes and to increase synthesis of cellular products, such as cytokines, transcription factors and structural proteins (NORIAN et al., 2015; FLETCHER et al., 1992). T-lymphocytes are activated by stimulation with Phytohemagglutinin (PHA) and Concanavalin A, whereas B lymphocytes are activated by stimulation with Pokeweed mitogen (ROITT, 1997). Activation of lymphocytes by mitogen Concanavalin A results in the proliferative response of the lymphocytes towards mitogen (FLETCHER et al., 1992) which stimulate differentiation of the T-lymphocytes into lymphoblasts, and induces mitosis, which increases the synthesis of nucleic acids, such as DNA, RNA and protein in T-lymphocytes (ITO et al., 1983; KRISTENSEN et al., 1982).

\section{Materials and methods}

Sample collection. All the dogs presented with the primary complaint of TVT in Veterinary Teaching Hospital, GBPUAT Pantnagar, were sexually intact at the time of presentation and diagnosis. Amongst them, some of the cases were in mixed breed while others were in pure breed dogs. Tissue and blood samples were obtained from a total of 12 TVT positive adult male and female dogs. Blood samples were collected weekly for the complete blood count (CBC) including some biochemical parameters like total serum protein and serum albumin. Chemotherapy with vincristine sulphate at the rate of $0.025 \mathrm{mg} / \mathrm{kg}$ intravenously was given at weekly interval. The treatment was continued until the total regression of tumour. The owners were asked to observe the behavior of the animal, changes in food and water intake, digestive alteration including vomiting, constipation and diarrhea during the chemotherapy. Signs of tumour regression or progression like tumour contraction, ulceration and increase or decrease in the tumour size and reduction in blood tinged discharge in urine were observed and noted. Tissue collection was done at weekly intervals starting from the progressive phase of TVT until one week after the complete remission of the tumour. Collected fresh tissue sample was washed thoroughly with generous amount of calcium-magnesium free phosphate buffer saline (CMF-PBS). CMF-PBS was rinsed completely. After the complete rinsing the tissue was transferred to glycerylated CMF-PBS at room temperature for at least one hour in a closed sterile container. Then it was further transferred to fresh glycerylated CMF-PBS at $4^{\circ} \mathrm{C}$ for $6-12$ hours in a closed sterile container. After 6-12 hours, processed tissue was transferred to the container at $-20^{\circ} \mathrm{C}$. Sufficient volume of glycerylated CMF-PBS was used to immerse the tissue completely. Sterility of the buffer was assured and temperature was properly maintained $\left( \pm 5^{\circ} \mathrm{C}\right)$ for the preservation of 
the tissue satisfactorily for up to 6-8 months of time period.

Sample preparation. Preserved tissue $(30 \mathrm{mg})$ was immediately weighed and ground thoroughly with a pestle and mortar. Ground tissue was processed for lysis followed by binding, washing and elution for isolation of the mRNA and reverse transcriptase PCR (Himedia Laboratories).

Qualitative RT-PCR analysis. PCR amplification analysis was performed using a primer pair for IL-6, TGF- $\beta 1$ and $\beta$-actin, as presented in the Table below.

Table 1. Primers for cytokines used in PCR amplification analysis

\begin{tabular}{|l|l|}
\hline Cytokines & Primers \\
\hline IL-6 & $\begin{array}{l}\text { Forward primer 50-TCCTGGTGATGGCTACTGCTT-30 } \\
\text { Reverse primer 50-GACTATTTGAAGTGGCATCATCCTT-30 }\end{array}$ \\
\hline TGF- $\beta 1$ & $\begin{array}{l}\text { Forward primer 50-CAGAATGGCTGTCCTTTGATGTC-30 } \\
\text { Reverse primer 50-AGGCGAAAGCCCTCGACTT-30 }\end{array}$ \\
\hline$\beta$-actin & $\begin{array}{l}\text { Forward primer 50-CCG CGA GAA GAT GAC CCA GA-30 } \\
\text { Reverse primer 50-GTG AGG ATC TTC ATG AGG TAG TCG G-30 }\end{array}$ \\
\hline
\end{tabular}

Primer design was performed as described by WANG et al. (2007). The Hiscript One Step RT-PCR kit (Himedia Laboratories) included 2X Reaction Mixture $25 \mu \mathrm{L}$, Reverse Transcriptase Enzyme Mix $1 \mu \mathrm{L}$, RNA template (10 pg to $1 \mu \mathrm{g}$ RNA) 4 $\mu \mathrm{L}$, Gene Specific Forward Primer $(10 \mu \mathrm{M}) 1 \mu \mathrm{L}$, Gene Specific Reverse Primer $(10 \mu \mathrm{M}) 1 \mu \mathrm{L}$ and Molecular Biology Grade Water up to $50 \mu \mathrm{L}$ for each reaction. Cycle conditions were: cDNA synthesis $45-60{ }^{\circ} \mathrm{C}$ for $15-30$ minutes, pre-denaturation $94{ }^{\circ} \mathrm{C}$ for 2 minutes, 40 cycles of denaturation $94^{\circ} \mathrm{C}$ for 15 seconds, annealing $60{ }^{\circ} \mathrm{C}$ for 30 seconds, extension $68{ }^{\circ} \mathrm{C}$ for 1 minute, and the final extension $68{ }^{\circ} \mathrm{C}$ for 5 minutes. The confirmation of the amplification of specific RT-PCR amplicon was performed by agarose gel electrophoresis (2\%). Amplified PCR products were size-fractionated by agarose gel electrophoresis on a $2.5 \%$ ethidium bromidestained agarose gel in Tris-Boric-EDTA (TBE) buffer, and visualized under a UV transilluminator.

Lymphocyte Stimulation Test. Fresh whole peripheral blood was collected for measuring the response of $\mathrm{T}$ cells to Concanavalin A (Con A) mitogen. The whole blood was diluted with an equal volume of CMF-PBS, and a $20 \mu \mathrm{L}$ aliquot of the resulting suspension was added to 200 $\mu \mathrm{L}$ of growth medium (RPMI-1640 with $1 \times$ streptopenicillin) plated in a 96-well plate. After 24 hours, mitogen Con A $(5 \mu \mathrm{g} / \mathrm{mL}$, Himedia laboratories), which induces blastogenesis and allows the cells to divide and proliferate, was added to the wells in triplicate. The plates were incubated at $37{ }^{\circ} \mathrm{C}, 5 \% \mathrm{CO}_{2}$ for 24 hours in a humidified chamber. At the end of the incubation period, $20 \mu \mathrm{L}$ of MTT (3-4, 5-dimethylthiazol2-yl-2, 5-diphenyltetrazolium bromide; Himedia laboratories) was added from the stock $(4 \mathrm{mg} / \mathrm{mL})$. The plates were re-incubated at the same condition for another 4 hours. Afterwards, $100 \mu \mathrm{L}$ of the culture supernatant was discarded carefully from each well. The formazan crystals formed were dissolved by adding $100 \mu \mathrm{L}$ dimethyl sulphoxide to each well. The optical densities (OD) of the stimulated wells with mitogen, and the unstimulated wells were detected on an ELISA plate reader at $570 \mathrm{~nm}$. Blastogenic responses were expressed as the mean stimulation index (SI), calculated by the formula given below (MAHMOUDI et al., 2011):

Mean stimulation index (SI) $=$ Mean OD) of the stimulated culture with mitogen / Mean OD of unstimulated control culture.

Evaluation of animal was done by clinical and hematological parameters prior to therapy with vincristine sulphate for monitoring the related side effects. Clinical parameters monitored in each patient included: respiration rate, heart rate, rectal temperature, hemoglobin concentration, total leukocyte count, differential leukocyte count, 
serum total protein, serum albumin, the presence or absence of blood-tinged discharge from the penis or vagina, and reduction in tumor size before and after the treatment.

\section{Results}

Gene expression of IL-6 and TGF- $\beta 1$. During the progressive stage of canine transmissible venereal tumor, TGF- $\beta 1$ was found to be secreted by CTVT cells. Its expression produced a stronger signal in the progressive phase than in the regressive phase of the canine transmissible venereal tumor (Fig. 2B, $2 \mathrm{C}$ ). However, the IL-6 cytokine expression was higher in the regressive phase of CTVT (Fig. 2A). Expression of the $\beta$-actin gene was also observed, but varied from animal to animal (Fig. 2D).
The statistical analysis was done using oneway analysis of variance (ANOVA) according to SNEDECOR and COCHRAN (1994). The study was conducted after obtaining the approval of the Institutional Animal Ethics Committee (IAEC).

Concanavalin A mitogen in $T$ lymphocytes. In this study, T- and B-lymphocytes were stimulated in vitro by a mitogen (Concanavalin $\mathrm{A}$ ) to measure an immune response. Concanavalin A (Con A) is a T-cell mitogen, that binds to the glycoproteins present on the cell surface of the lymphocytes. Significant $(\mathrm{P}<0.05)$ increase in the mean stimulation index of the lymphocyte stimulation test were observed after chemotherapy in the CTVT affected animals (Fig. 3A).
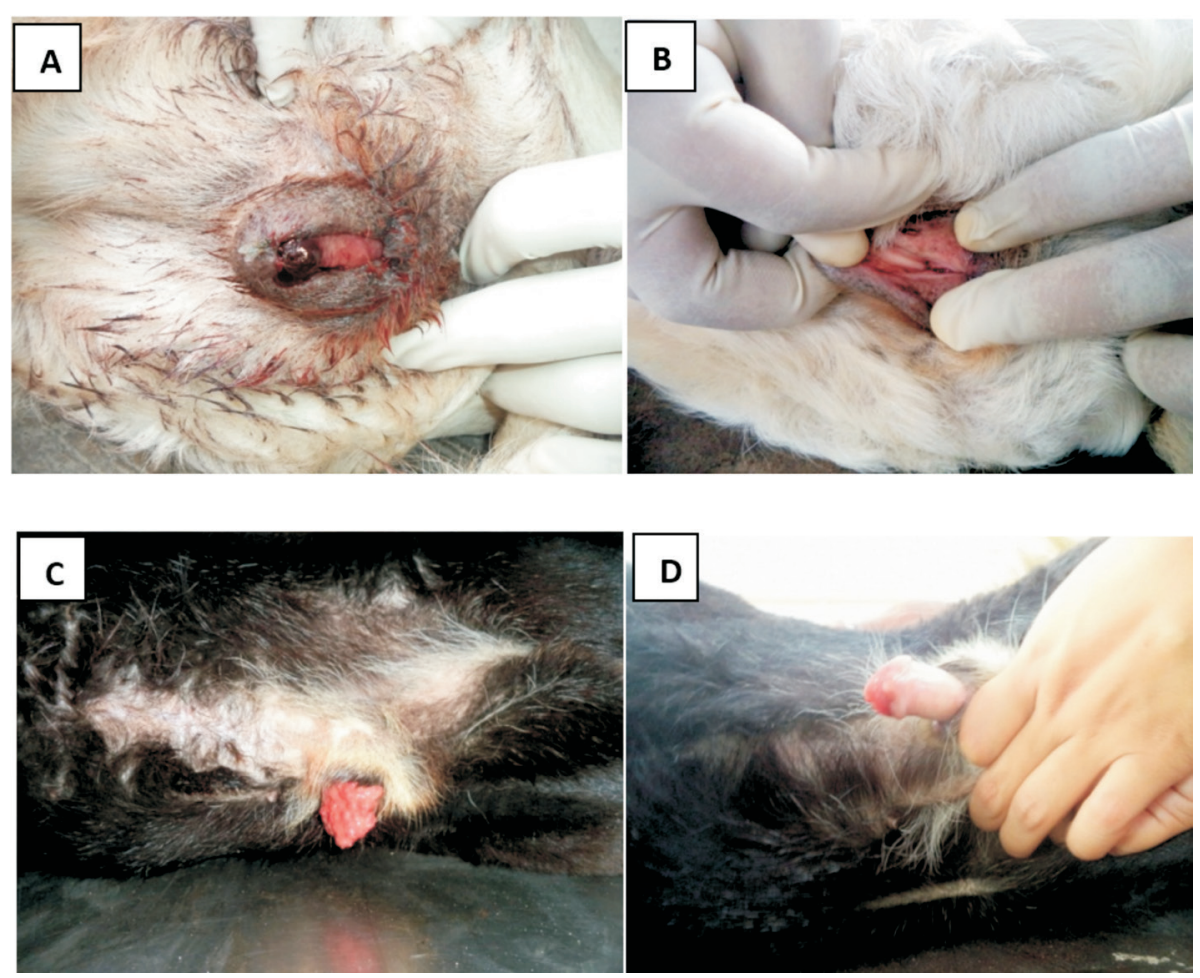

Figs. 1. A and C - Gross appearance of CTVT at 0 weeks before chemotherapy. Figs. B and D - Gross appearance of CTVT at 3 weeks with a progressive decrease in tumor mass after chemotherapy. 


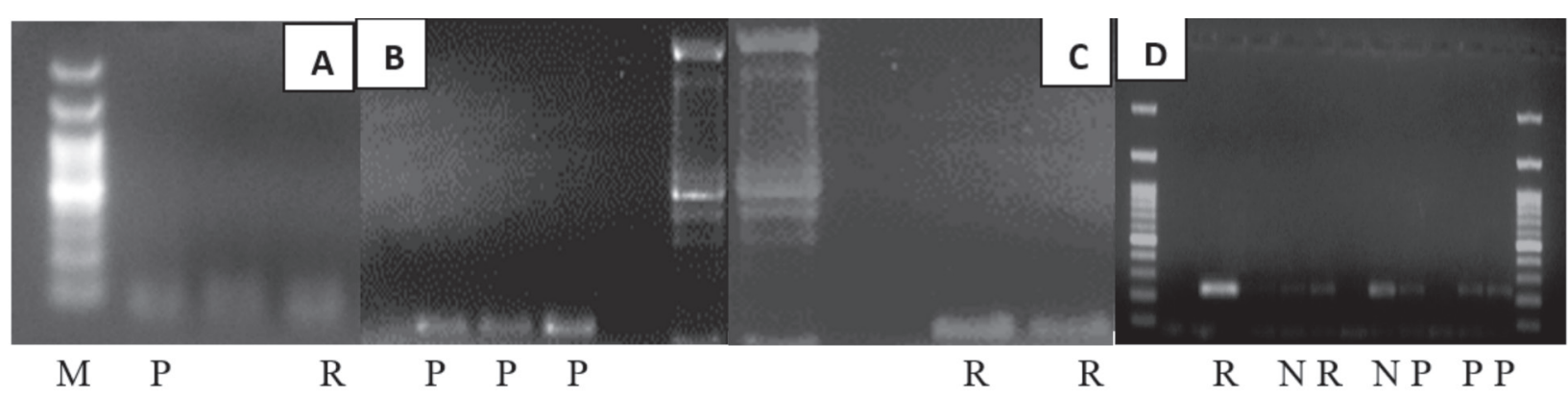

Fig. 2. A- RT-PCR amplification product of IL-6 cytokine during the progressive and regressive phases of CTVT. BRT-PCR amplification product of TGF- $\beta 1$ cytokine in the progressive phase of the tumor. C- RT-PCR amplification product of TGF- $\beta 1$ cytokine in the regressive phase of the tumor. D- RT-PCR amplification product of $\beta$-actin in a normal $(\mathrm{N})$ animal sample, and the progressive $(\mathrm{P})$ and regressive $(\mathrm{R})$ phases of tumor samples.

Lane M: 100 bp molecular weight marker. Lane P\&R: 79 bp RT-PCR product.

Table 2. Tabular representation of mean \pm SE values of various parameters at weekly intervals from 0 day to week 3 in CTVT affected animals

\begin{tabular}{|l|c|c|c|c|c|}
\hline $\begin{array}{l}\text { Periods } \\
(\text { Weeks })\end{array}$ & $\begin{array}{c}\text { TLC } \\
\left(10^{3} / \mu \mathrm{L}\right)\end{array}$ & $\begin{array}{c}\text { Lymphocyte Proliferation Assay } \\
(\text { mean stimulation index })\end{array}$ & $\begin{array}{c}\text { Monocyte } \\
(\%)\end{array}$ & $\begin{array}{c}\text { Serum Albumin } \\
(\mathrm{g} / \mathrm{L})\end{array}$ & $\begin{array}{c}\text { Serum Total } \\
\text { Protein }(\mathrm{g} / \mathrm{L})\end{array}$ \\
\hline 0 Week & $5.58 \pm 0.42$ & $1.366 \pm 0.100$ & $3 \pm 0.28$ & $23.5 \pm 0.06$ & $50.2 \pm 0.50$ \\
\hline $1^{\text {st }}$ Week & $5.42 \pm 0.34$ & $1.248 \pm 0.076$ & $2.83 \pm 0.34$ & $22.3 \pm 0.07$ & $48.2 \pm 0.50$ \\
\hline $2^{\text {nd }}$ Week & $6.41 \pm 1.19$ & $1.411 \pm 0.096$ & $4.17 \pm 1.28$ & $22.4 \pm 0.06$ & $46.3 \pm 0.43$ \\
\hline $3^{\text {rd }}$ Week & $7.03 \pm 0.64$ & $1.415 \pm 0.085$ & $4.67 \pm 0.73$ & $22.2 \pm 0.06$ & $47.4 \pm 0.29$ \\
\hline
\end{tabular}

Table 3. Tabular representation of mean \pm SE values of various parameters at weekly intervals from 0 day to week 3 in CTVT affected animals

\begin{tabular}{|l|c|c|c|}
\hline $\begin{array}{l}\text { Periods } \\
(\text { Weeks })\end{array}$ & $\begin{array}{c}\text { Respiration Rate } \\
(/ \text { minute })\end{array}$ & $\begin{array}{c}\text { Heart Rate } \\
(/ \text { minute })\end{array}$ & $\begin{array}{c}\text { Rectal Temperature } \\
\left({ }^{\circ} \mathrm{C}\right)\end{array}$ \\
\hline 0 Week & $27.33 \pm 1.22$ & $93 \pm 2.43$ & $38.65 \pm 0.07$ \\
\hline $1^{\text {st }}$ Week & $25.66 \pm 0.03$ & $91.33 \pm 5.46$ & $38.64 \pm 0.19$ \\
\hline $2^{\text {nd }}$ Week & $24.67 \pm 0.92$ & $88.33 \pm 4.16$ & $38.68 \pm 0.21$ \\
\hline $3^{\text {rd }}$ Week & $26.67 \pm 0.46$ & $90.66 \pm 5.00$ & $38.57 \pm 0.12$ \\
\hline
\end{tabular}

Table 4. Tabular representation of mean \pm SE values of various parameters at weekly intervals from 0 day to week 3 in CTVT affected animals

\begin{tabular}{|l|c|c|c|}
\hline Periods (Weeks) & Haemoglobin $(\mathrm{g} / \mathrm{L})$ & Lymphocytes $(\%)$ & Neutrophils (\%) \\
\hline 0 Week & $148 \pm 1.02$ & $20.66 \pm 1.69$ & $38.65 \pm 0.07$ \\
\hline $1^{\text {st }}$ Week & $149 \pm 1.25$ & $17 \pm 1.52$ & $38.64 \pm 0.19$ \\
\hline $2^{\text {nd }}$ Week & $162.7 \pm 0.66$ & $23.16 \pm 0.66$ & $38.68 \pm 0.21$ \\
\hline $3^{\text {rd }}$ Week & $170 \pm 0.64$ & $29.17 \pm 1.00$ & $38.57 \pm 0.12$ \\
\hline
\end{tabular}


Variation in blood parameters in tumor affected animals. The hemoglobin levels showed a slight and non-significant $(\mathrm{P}>0.05)$ decrease in tumor affected animals. However, after chemotherapy, there was a significant $(\mathrm{P}<0.05)$ increase in the hemoglobin levels in TVT affected animal, which returned to the normal range after two weeks of chemotherapy (Fig. 3C and Table 4). Non-significant $(\mathrm{P}>0.05)$ decreases in the total leukocyte count were observed in the tumor affected animals.
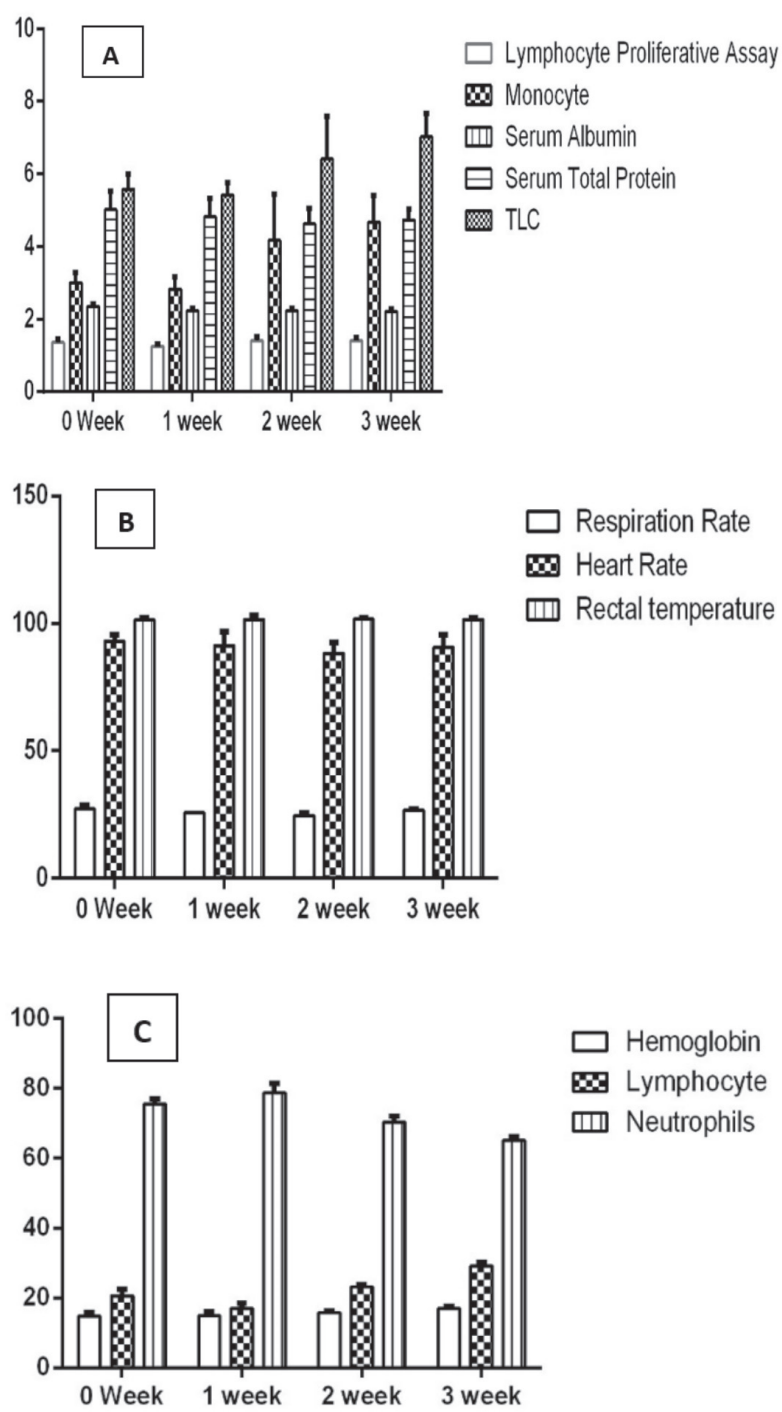

Fig. 3. Graphical representation of mean \pm S.E values of various parameters at weekly intervals from 0 day to week 3 in CTVT affected animals
After two weeks of chemotherapy, slight leukocytosis was observed in all the animals, indicating a positive immune response in the affected animals. Regarding the differential leukocyte count, slight lymphopenia was observed in the CTVT affected animals. After chemotherapy with vincristine sulphate, there was slight lymphocytosis, neutropenia and monocytosis (Fig. $3 \mathrm{~A}$ and C; Table 2 and 4). Slight hypoproteinemia and slight hypoalbuminemia were observed in the tumor affected animals during chemotherapy (Fig. $3 \mathrm{~A}$ and Table 2).

Clinical examination of the dogs revealed progressive decrease of tumour masses and absence of dropping of blood occurring within first week of chemotherapy. At the end of treatment, no TVT mass were detected on twelve dogs (Fig.1). Non-significant $(\mathrm{P}>0.05)$ changes were recorded in the respiration rate, rectal temperature and heart rate during the chemotherapy of the CTVT affected dogs (Fig. 3b and Table 3). Some owners reported decrease on food intake (4 dogs), no vomiting, diarrhea $(1 \mathrm{dog})$ and no dermatological and hypersensitivity reaction during and after the chemotherapy.

\section{Discussion and conclusions}

Transforming growth factor beta-1 (TGF- $\beta 1$ ) is one of the potent inhibitors of immune function secreted by tumors (REISS, 1999; GOLD, 1999; GILBOA, 1999). During the progressive stage of canine transmissible venereal tumor (CTVT), TGF- $\beta 1$ was secreted by CTVT cells. Its expression was more significant in the progressive phase than in the regressive phase of CTVT, and it might suppress lymphokine activated killer (LAK) cytotoxicity and the immune system of the CTVT affected dogs. TGF- $\beta 1$ and IL- 6 cytokines were inversely interrelated with each other. Expression of IL-6 cytokine was significant in the regressive phase of CTVT as compared to the progressive phase of CTVT, which indicated that the increased secretion might be due to the increased tumor infiltrating lymphocytes. A similar finding was also observed by HSAIO et al. (2004). Tumor infiltrating lymphocyte (TIL) also produces interleukin-6 (IL6) during the progressive phase of the tumor, but the concentration of IL- 6 is too low to antagonize 
the TGF- $\beta 1$, which results in a decrease in the immunity of the CTVT affected animal. This causes the tumor cells to proliferate (CHOU et al., 2009; HSIAO et al., 2002; HSIAO et al., 2004).

Lymphocytes are the cells responsible for recognizing foreign antigens and mounting the immune response. A significant $(\mathrm{P}<0.05)$ increase in the mean stimulation index of the lymphocyte stimulation test was observed before and after the chemotherapy. A similar observation was reported by CHANDLER and YANG (1981). This increase in the mean stimulation index in the lymphocyte stimulation test is indicative of a higher number of T-lymphocytes in the whole blood collected after chemotherapy, which indicates the presence of cell mediated immunity in the CTVT affected animal during the regressive phase of the tumor.

Before the treatment, the hemoglobin level was slightly lower in CTVT affected animals, but after chemotherapy, the hemoglobin level increased in CTVT affected animals which might be due to chronic loss of blood or reduced water intake. Similar finding were also observed by NAK et al. (2005). Slight leukopenia and lymphocytosis were observed in CTVT affected animals, which indicates the immune response of the CTVT affected animals after chemotherapy. Non-significant $(\mathrm{P}>0.05)$ changes were observed in the number of neutrophils, lymphocytes, monocytes and eosinophils after chemotherapy. Similar results were also observed by DAS et al. (1991a, b) and SHARMA et al. (2011). Slight hypoproteinemia and hypoalbuminemia were observed in TVT affected animals after chemotherapy with vincristine sulphate, which indicates that regular chemotherapy might have a slight effect on the liver. Similar observations were also recorded by BEHERA et al. (2012). These results could estimate the risk of hematological alterations after vincristine treatment, considering the initial references.

Cell mediated immunity and cytokine IL-6 may have a potential application in the regression of the tumor after chemotherapy. The combination of immunotherapy with IL-6 and chemotherapy with vincristine sulphate might be much more effective in the treatment of CTVT. Our study also concluded that RT-PCR assay for the detection of cytokines may help in improving the accuracy of the diagnosis of the different phases of CTVT, which helps to identify the prognosis of the disease in the animal. Knowing the severity of the disease helps the veterinarian to treat the disease accordingly, which increases the animals' survival rate. This RT-PCR based approach may also assist the veterinarian to make decisions whether to discontinue the chemotherapy by discriminating between residual tumor cell masses and fibrotic tissue.

\section{Acknowledgment}

The authors are grateful to Dean, College of Veterinary \& Animal Science, GBPUA\&T, Pantnagar for providing facilities for this study

\section{References}

BEHERA, S. K., N. P. KURADE, S. W. MONSANG, D. P. DAS, K. K. MISHRA, R. K. MOHANTA (2012): Clinicopathological findings in a case of canine cutaneous metastatic transmissible venereal tumor. Vet. arhiv 82, 401-410.

CANO, R. L. E., H. D. E. LOPERA (2013): Introduction to $\mathrm{T}$ and B lymphocytes. In: Autoimmunity: From Bench to Bedside [Internet]. El Rosario University Press, Bogota, Colombia.

CASTRICONI, R., C. CANTONI, M. DELlA CHIESA, M. VITALE, E. MARCENARO, R. CONTE, R. BIASSONI, C. BOTTINO, L. MORETTA, A. MORETTA (2003): Transforming growth factor beta 1 inhibits expression of NKp30 and NKG2D receptors: consequences for the NKmediated killing of dendritic cells. Proc. Natl. Acad. Sci. U.S.A.100, 4120-4125.

DOI:10.1073/pnas.0730640100

CHANDLER, J. P., T. J. YANG (1981): Canine transmissible venereal sarcoma: distribution of $\mathrm{T}$ and $\mathrm{B}$ lymphocytes in blood, draining lymph nodes and tumours at different stages of growth. Br. J. Cancer. 44, 514-521.

DOI: $10.1038 /$ bjc. 1981.220

CHOU, P. C., T. F. CHUANG, T. R. JAN, H. C. GION, Y. C. HUANG, H. J. LEI, W. Y. CHEN, R. M. CHU (2009): Effects of immunotherapy of IL-6 and IL-15 plasmids on transmissible venereal tumour in beagles. Vet. Immunol. Immunopathol. 130, 25-34.

DOI: $10.1016 /$ j.vetimm.2009.01.002

CHU, R. M., C. Y. LIN, C. C. LIU, S. Y. YANG, Y. W. SIAO, S. W. HUN (2001a): Proliferation characteristics of canine transmissible venereal tumour. Anticancer Res. 21, 4017-4024.

CHU, R. M., T. J. SUN, H. Y. YANG, D. G. WANG, K. W. LIAO, T. F. CHUANG, C. H. LIN, W. C. LEE (2001b): Heat shock proteins in canine transmissible venereal tumour. Vet. Immunol. Immunopathol. 82, 9-21.

CRANE, J. L., X. CAO (2014): Bone marrow mesenchymal stem cells and TGF-beta signaling in bone remodeling. J. Clin. Invest. 124, 466-472.

DOI:10.1172/jci70050 
K. Tiwari et al.: Immune-mediated gene expression of IL-6 and TGF- $\beta 1$ during progression and regression of canine transmissible venereal tumour

DAS, A. K., U. DAS, D. K. DAS, J. SENGUPTA, B. B. DAS, P. K. BOSE (1989): Metastasis of canine transmissible venereal sarcoma (CTVS) in a dog. Indian J. Vet. Surg. 10, 74-75.

DAS, U., A. K. DAS, D. DAS, B. B. DAS (1991a): Clinical report on the efficacy of chemotherapy in canine transmissible venereal sarcoma. Indian Veterinary Journal. $68,249-252$.

DAS, A. K., U. DAS, D. DAS (1991b): A clinical report on the efficacy of vincristine on canine transmissible venereal sarcoma. Indian Veterinary Journal. 68, 575-576.

DAS, U., A. K. DAS (2000): Review of canine transmissible venereal sarcoma. Vet. Res. Commun. 24, 545-556.

DOI: 10.1023/a:1006491918910.

FLETCHER, B. S., D. A. KUJUBU, D. M. PERRIN, H. R. HERSCHMAN (1992): Structure of the mitogen-inducible TIS10 gene and demonstration that the TIS10-encoded protein is a functional prostaglandin $\mathrm{G} / \mathrm{H}$ synthase. J. Biol. Chem. 267, 4338-4344.

DOI: $10.1016 / \mathrm{s} 0021-9258(18) 42840-2$

GANGULY, B., U. DAS, A. K. DAS (2016): Canine transmissible venereal tumour: a review. Vet. Comp. Oncol. 14, 1-12.

DOI: $10.1111 / \mathrm{vco} .12060$

GILBOA, E. (1999): How tumors escape immune destruction and what we can do about it. Cancer Immunol. Immunother. 48, 382 .

DOI: $10.1007 / \mathrm{s} 002620050590$

GOLD, L. I (1999): The role for transforming growth factor (TGF) in human cancer. Crit. Rev. Oncog. 10, 303.

GONZALEZ, C. M., S. M. GRIFFEY, D. K. NAYDAN, E. FLORES, R. CEPEDA, G. CATTANEO, B. R. MADEWELL (2000): Canine transmissible venereal tumour: a morphologic and immunohistochemical study of 11 tumours in growth phase and during regression after chemotherapy. J. Comp. Pathol. 122, 241-248.

DOI: $10.1053 /$ jcpa.1999.0366

GORELIK, L., R. A. FLAVELL (2001): Immune-mediated eradication of tumours through the blockade of transforming growth factor- $\beta$ signaling in T cells. Nature Med.7, 1118-1122.

DOI: $10.1038 / \mathrm{nm} 1001-1118$

HAQUE, S., J. C. MORRIS (2017): Transforming growth factor- $\beta$ : A therapeutic target for cancer. Hum. Vaccin. Immunother. 8, 1741-1750.

HSIAO, Y. W., K. W. LIAO, T. F. CHUNG, C. H. LIU, C. D. HSU, R. M. CHU (2008): Interactions of host IL-6 and IFNgamma and cancer-derived TGF-betal on MHC molecule expression during tumour spontaneous regression. Cancer Immunol. Immunother. 57, 1091-1104. DOI: $10.1007 /$ s00262-007-0446-5

HSIAO, Y. W., K. W. LIAO, S. W. HUNG, R. M. CHU (2002): Effect of tumour infiltrating lymphocytes on the expression of MHC molecules in canine transmissible venereal tumour cells. Vet. Immunol. Immunopathol. 87, 19-27.

DOI: $10.1016 / \mathrm{s} 0165-2427(02) 00026-0$

HSIAO, Y. W., K. W. LIAO, S. W. HUNG, R. M. CHU (2004): Tumour-infiltrating lymphocyte secretion of IL-6 antagonizestumour-derived TGF-beta 1 and restores the lymphokine-activated killing activity. J. Immunol. 172, 1508-1514.

DOI: $10.4049 /$ jimmunol.172.3.1508

ITO, Y., I. FUKAMACHI, K. NAKAJIMA, T. KWAI, K. NAKANO (1983): A new method for the evaluation of lymphocyte activation by ethidium bromide fluorescence assays. Igaku-no-Ayumi. 126, 21-22.

KRISTENSEN, F., B. KRISTENSEN, S. LAZARY (1982): The lymphocyte stimulation test in veterinary immunology. Vet. Immunol. Immunopathol. 3, 203-277.

DOI: $10.1016 / 0165-2427(82) 90036-8$

LI, M. O., Y. Y. WAN, S. SANJABI, A. K. ROBERTSON, R. A. FLAVELL (2006): Transforming growth factor-beta regulation of immune responses. Ann. Rev. Immunol. 24, 99-146.

DOI: 10.1146/annurev.immunol.24.021605.090737

LIN, C. H., W. Y. CHION, L. L. CHUEN, L. E. SHIEH, R. M. CHU (2010): Deterioration and metastasis of a canine transmissible venereal tumor in a dog associated with a CPV-2. Taiwan Vet. J. 36, 191-200.

LIN, C. Y., T. F. CHUANG, K. W. LIAO, Y. J. HUANG, C. C. PAI, R. M. CHU (2008): Combined immunogene therapy of IL- 6 and IL-15 enhances anti-tumour activity through augmented NK cytotoxicity. Cancer Lett. 272, 285-295. DOI: 10.1016/j.canlet.2008.07.016

MAHMOUDI, M. J., M. MAHMOUDI, F. SIASSI, F. SHOKRI, M. ESHRAGHIAN, A. ZAMANI, R. CHAHARDOLI, M. HEDAYAT, J. KHOSHNOODI, H. NAYERI, N. REZAEI, A. SABOOR-YARAGHI (2011): Lymphocyte cytotoxicity of oxLDL in patients with atherosclerosis. Iranian Journal of Immunology 8, 27-33.

DOI: $10.1016 /$ j.jaci.2010.12.922

MARCOS, R., M. SANTOS, C. MARRINHAS, E. ROCHA (2006): Cutaneous transmissible venereal tumor without genital involvement in a prepubertal female dog. Vet. Clin. Path. 35, 106-109.

DOI: $10.1111 / j .1939-165 x .2006 . t b 00097 . x$

MUKARATIRWA, S., E. GRUYS (2003): Canine transmissible venereal tumor: Cytogenetic origin, immunophenotype, and immunobiology. A review. Vet. Q. 25, 101-111. DOI: 10.1080/01652176.2003.9695151

MUKARATIRWA, S., T. CHIWOME, S. CHITANGA, E. BHEBHE (2006): Canine transmissible venereal tumour: Assessment of mast cell numbers as indicators of the growth phase. Vet. Res. Commun. 30, 613-621. DOI: $10.1007 / \mathrm{s} 11259-006-3309-1$

MURCHISON, E. P. (2008): Review: Clonally transmissible cancers in dogs and Tasmanian devils. Oncogene. 2, S19-30. DOI: $10.1038 /$ onc. 2009.350

MURCHISON, E. P., D. C. WEDGE, L. B. ALEXANDROV, B. FU, I. MARTINCORENA, Z. NING, J. M. TUBIO, E. I. WERNER, J. ALLEN, A. B. DE NARDI, E. M. DONELAN (2014): Transmissible dog cancer genome reveals the origin and history of an ancient cell lineage. Science 343, 437-440. DOI: $10.1126 /$ science. 1247167

NAK, D., Y. NAK, I. T. CANGUL, B. TUNA (2005): A Clinico-pathological study on the effect of vincristine 
K. Tiwari et al.: Immune-mediated gene expression of IL- 6 and TGF- $\beta 1$ during progression and regression of canine transmissible venereal tumour

on transmissible venereal tumour in dogs. J. Vet. Med. A Physiol. Pathol. Clin. Med. 52, 366-370.

DOI: $10.1111 /$ j.1439-0442.2005.00743.x

NORIAN, R., N. DELIREZH, A. AZADMEHR (2015): Evaluation of proliferation and cytokines production by mitogen-stimulated bovine peripheral blood mononuclear cells. In Vet. Res. Forum. 6, 265.

REISS, M. (1999): TGF- $\beta 1$ and cancer. Microbes Infect. 1, 1327.

RICH, J., A. BORTON, X. WANG (2001): Transforming growth factor-beta signaling in cancer. Microsc. Res. Tech. 52, 363-373.

ROITT, I. M. (1997): Roitt's essential immunology. Blackwell Science Ltd, London, pp. 216.

SHARMA, A. K., H. KUMAR, C. K. CHOUDHARY, L. L. DASS (2011): Haemato-biochemical changes in dogs affected with canine transmissible venereal tumour. Ind. J. Vet. Med. 31, 26-27.

SNEDECOR, G. W., W. G. COCHRAN (1994): Statistical Methods, $7^{\text {th }}$ ed. Oxford and I.B.M. Publication, Bombay.

STOCKMANN, D., F. F. HEITOR, L. A. ALEXANDRE, A. L. RODRIGO, C. C. TEREZA, C. R. L. MARIA (2011): Canine transmissible venereal tumours: aspects related to programmed cell death. Braz. J. Vet. Pathol. 4, 67-75.
STOVER, D. G., B. BIERIE, H. L. MOSES (2007): A delicate balance: TGF-beta and the tumour microenvironment. J. Cell. Biochem. 101, 851-861.

DOI: $10.1002 /$ jcb. 21149

TEICHER, B. A. (2007): Transforming growth factor-beta and the immune response to malignant disease. Clin. Cancer Res.13, 6247-6251.

DOI: $10.1158 / 1078-0432 . c c r-07-1654$

WANG, Y. S., K. H. CHI, R. M. CHU (2007): Cytokine profiles of canine monocyte-derived dendritic cells as a function of lipopolysaccharide or tumor necrosis factor-alpha-induced maturation. Vet. Immunol. Immunopathol. 118, 186-198. DOI: 10.1016/j.vetimm.2007.05.010

WITHAM, T. F., L. VILLA, T. YANG, I. F. POLLACK, H. OKADA, P. D. ROBBINS, W. H. CHAMBERS (2003): Expression of a soluble transforming growth factor-beta (TGFbeta) receptor reduces tumourigenicity by regulating natural killer (NK) cell activity against 9L gliosarcoma in vivo. J. Neurooncol. 64, 63-69.

DOI: $10.1007 / \mathrm{bf02700021}$

UJVARI, B., A. T. PAPENFUSS, A. T. PAPENFUSS, K. BELOV (2016): Transmissible cancers in an evolutionary context. Inside the cell. 1, 17-25. DOI: $10.1002 /$ icl3.1020

Received: 7 May 2020

Accepted: 16 March 2021

TIWARI, K., P. VERMA, J. SHARMA, A. K. UPADHYAY;A. K. DAS: Imunosno posredovana genska ekspresija IL-6 i TGF-ß1 za vrijeme progresije i regresije zaraznog veneričnog tumora u pasa. Vet. arhiv 91, 625-634, 2021.

\section{SAŽETAK}

Zarazni venerični tumor u pasa (CTVT) jedinstven je, prirodno i eksperimentalno prenosiv kontagiozni venerični tumor, koji se obično nalazi u pasa lutalica s nekontroliranom seksualnom aktivnošću. Uzrokuje ga mutirana i kontagiozna tumorska stanica. Ovo je istraživanje provedeno kako bi se procijenila genska ekspresija citokina TGF- $\beta 1$ i IL-6, odgovor T-stanica na konkanavalin A te hematološke i biokemijske promjene za vrijeme progresije i regresije CTVT-a. Zabilježeni su klinički znakovi i povijest bolesti 12 pasa sa zaraznim veneričnim tumorom. Uzorci tkiva dobiveni su biopsijom i krvnim uzorcima prikupljenima za dijagnostičku potvrdu upotrebom PCR reverzne transkriptaze. RT-PCR produkti CTVT uzoraka zatim su pročišćeni i sekvencirani. Tumorska je regresija postignuta tjednim intravenskim injekcijama vinkristin-sulfata. Znakovita genska ekspresija TGF- $\beta 1$ uočena je u fazi progresije CTVT-a, dok je genska ekspresija IL-6 bila znakovita u fazi regresije CTVT-a nakon kemoterapije. Stanično posredovana imunost također je važna u regresiji zaraznog veneričnog tumora. Opažen je znakovit porast $(\mathrm{P}<0,05)$ prosječnog stimulacijskog indeksa limfocitnog stimulacijskog testa i razine hemoglobina, neznakovite promjene $(\mathrm{P}>0,05)$ broja neutrofila, limfocita, monocita i eozinofila te blaga hipoproteinemija i hipoalbuminemija poslije kemoterapije vinkristin-sulfatom u životinja s CTVT-om. Sveukupno rezultati naznačuju ključnu ulogu T-stanica, TGF- $\beta 1$ i IL-6 u poticanju regresije i progresije CTVT-a, što može biti obećavajuće u razvoju potencijalne imunoterapije za CTVT.

Ključne riječi: zarazni venerični tumor u pasa; RT-PCR; TGF- $\beta 1$, IL-6; limfocitni stimulacijski test; hematološke i biokemijske promjene; vinkristin-sulfat 